\title{
RESOURCE CHANGE REPRESENTATION IN THE RUSSIAN POPULATION AFTER THE FIRST THREE MONTHS OF THE COVID-19 PANDEMIC OUTBREAK
}

\author{
F.M. SHANKOV ${ }^{\mathrm{a}}$, M.A. CHUMAKOVA, ${ }^{\mathrm{a}, \mathrm{b}}$, M.S. VASILCHUK ${ }^{\mathrm{b}}$, \\ N.V. KISELNIKOVA (VOLKOVA) ${ }^{\mathrm{a}}$
}

\author{
${ }^{a}$ FBSSI Psychological Institute of the Russian Academy of Education, 9, Bld 4, Mokhovaya Str., Moscow, \\ 125009, Russian Federation \\ ${ }^{b}$ HSE University, 20 Myasnitskaya Str., Moscow, 101000, Russian Federation
}

\begin{abstract}
The 2019 Coronavirus disease outbreak leads to negative psychological outcomes not only for healthcare workers and patients, but also for the general public. S. Hobfoll's Conservation of Resources theory is one of the most applicable models for conceptualizing and evaluating natural and social catastrophes and their impact. A web-based screening has been conducted at the end of May, 2020. A representation of resource loss, threat of loss, gain, and value data was collected three months after first patient and restrictions. After meeting an inclusion criterion, data of 1100 respondents have been selected for the analysis. Basing on literature review, four comparison groups were formed: COVID-19 patients $(\mathrm{N}=65)$; single male respondents aged from 18 to 34 with low financial income $(\mathrm{N}=42)$; female respondents aged from 18 to 34 with low financial income who share living space with more than two persons $(\mathrm{N}=32)$; a "resourceful" group of male participants aged from 35 to 54 with high income and ongoing relationships $(\mathrm{N}=54)$. Descriptive statistics and Cohen's d criteria are applied. Measures: social-demographic questionnaire and modified COR-E questionnaire. Resource change due to the pandemic circumstances in general population appears to be modest. Threat of resource loss is higher than real resource loss. The COVID-19 situation mostly impacted following resources: Financial Stability, Feeling of Safety, Sense of Control in Life, Sense of Independence, Intimates' Health, and Work Stability. Comparison groups show significant differences in resource change constellations consistent with similar data from other countries.
\end{abstract}

Keywords: personal resources, COVID-19, conservation of resources theory, resources evaluation, stress, lockdown, coping, resilience.

\section{Introduction}

After the World Health Organization on March 11, 2020 declared the novel coronavirus (COVID-19) to be a pandemic, the Russian Federation, along with other countries, took immediate measures to control its spread by applying strict measures such as self-isolation, social distancing, specific demands for workers, and other restrictions. This worldwide situation evolved into a crisis that affected 
almost every aspect of individual lives and social life and can be seen as a natural and social catastrophe comparable with war, terror, and natural disasters. All these events result in severe psychological distress and a grave threat to primary human resources and needs. Several meta-analytical studies (Cénat et al., 2021; Krishnamoorthy et al., 2020; Xiaong et al., 2020) have shown that after the COVID-2019 pandemic among the general population there is a high risk of developing such negative psychological outcomes as depression (14.6\% to $48.3 \%$ ), anxiety (6.33\% to 50.9\%), and PTSD (7\% to 53.8\%). High-risk groups of the population for developing these outcomes are predicted in these studies to be people who suffered from the coronavirus disease, female younger than 40 years old, people having chronic or psychiatric illnesses, unemployed, students, healthcare providers, and single young adults. The current web-based screening aims to reveal the early stages of developing negative psychological outcomes within similar vulnerable groups in Russia.

To approach this goal, we chose to draw upon S. Hobfoll's Conservation of Resources theory (COR) and evaluation (COR-E) for several reasons: 1. COR has significant experience in the research and conceptualization of catastrophes (Hobfoll, 2012); 2. COR theory and evaluation presents an ecological approach, taking into account not just given outcomes, as do subjective stress scales and stress-related impairments, but revealing what lies behind the severe stress response: considerable loss or threat of valued resources (Hobfoll et al., 2016); 3. Empirical studies show that resource loss is relatively more important in predicting psychological distress than personal characteristics and coping behavior (Freedy et al., 1992; Ironson et al., 1997); 4. COR theory in its implications suggests evidence-based specific social and personal interventions (Hobfoll et al., 2007; Hobfoll et al., 2016).

However, there are also two major critical concerns to the COR theory. First, it has been criticized for not having a particular definition of resources (Gorgievski et al., 2011), and for not regarding the subjective value of particular resources (Halbesleben et al., 2014; Morelli \& Cunningham, 2012). In the current study, we aim to take into account these recommendations by modifying COR-E (see the Measures section). Thus, in the current study, we aim to make a first attempt at characterizing the general population and previously identified vulnerable groups in terms of their representation of resource change (loss, threat, gain, and value) three months after the COVID-2019 pandemic outbreak in Russia.

\section{Measures}

Screening in total contained several blocks, the first two of which are included in the current analysis.

\section{Socio-demographic questionnaire}

The first block consisted of questions regarding social-demographic personal characteristics such as sex/gender, country, region, city, age, education, family status, amount of people staying together during self-isolation, days in self-isolation, financial income, health issues. 


\section{Modified COR evaluation questionnaire}

The second block contained a modification of Steven Hobfoll's Conservation of Resources evaluation questionnaire (COR-E). The original COR-E consisted of 74 resources (Hobfoll \& Lilly, 1993), however, in different studies the number of resources varied depending on the research task (e.g. 12 resources in the study by Davidson et al. (2010), and 30 in Russian adaptation (Shteyn et al., 2003)).

We categorized and proposed 18 resources based on suggestions by ten Brummelhuis and Bakker (2012) and suggestions by sociology and psychotherapy experts: 1. Good sleep; 2. Free/personal time; 3. Good relationship with intimates; 4. Family stability; 5. Personal health; 6 . Intimates' health; 7. Good relationships with at least one friend; 8 . Work status; 9 . Work stability; 10. Support from colleagues; 11. Financial stability; 12. Sense of independence; 13. Sense of a goal and a meaning in life; 14. Sense of control of life; 15. Things and material resources (car, clothes, good food, home, etc.); 16. Sense of being competent and successful; 17. Hope and optimism; 18. Sense of safety (national, family, social, personal).

Based on other critical recommendations (Halbesleben et al., 2014; Morelli \& Cunningham, 2012), we also, apart for two original scales (loss, gain), included two additional scales (threat of loss, resource value).

Participants were asked to read through instructions attentively. Each parameter of evaluation (the real loss, threat of loss, gain, value) has been defined. Respondents were asked to rate how the availability of specific resources had changed during the last two months. An attention check question was put at the end of the instruction to select only those participants who carefully followed instructions: "For attention check please mark 0 in the Threat of Resource loss for the "Good sleep" resource" (this question was excluded from data statistical analysis).

\section{Sample and Procedure}

Data was gathered online via the 1KA platform (https://www.1ka.si). There were 48 hours of survey distribution. Participants were Yandex.Toloka users (https://toloka.yandex.com), who received a 30 rubles payment each for completing the questionnaire and answering correctly to the attention check question (see the Measures section). The informed consent contained a description and contacts of the organization and researchers responsible for the study, the research goal, tasks for respondents, approximate time, risks and gains for a participant, reward conditions, and voluntary participation.

In total one thousand and nine hundred participants attended the online screening form on the $1 \mathrm{KA}$ platform. In order to withdraw invalid data, we used the following criteria of inclusion: 1. Participants currently live in Russia; 2. Participants answered all questions of the screening survey; 3. Participants answered correctly to the attention check question; 4 . Participants took more than 5 minutes 33 seconds to fill the whole screening survey and also didn't have repeated patterns of answers. After applying these criteria, there was a total of 1,100 participants' data included for further analysis, $53.4 \%$ female, $46.6 \%$ male. Age ranged 
from 18 to 74: 18-24 (18.3\%), 25-34 (36.4\%), 35-44 (27.7\%), 45-54 (11.7\%), 55-64 (4.8\%), 65-74 (1.1\%). Financial income level: low (31.3\%), average (31.1\%), high (37.6\%). Level of education: with a degree (55.1\%), secondary and post-secondary school, $44.9 \%$. The majority of participants are in a relationship (62.2\%), 37.8\% are single. Participants represent all 84 regions of Russia, almost equally from cities with a million-plus population (49.5\%) and regular cities (50.5\%). Other socio-demographic data was used within group formations.

Drawing upon existing literature analysis, we formed three vulnerable groups and one potentially resilient group of participants from the general sample by combining particular socio-demographic parameters.

1. The first formed group consisted of participants that checked as recovering from severe acute respiratory syndrome coronavirus 2 (COVID patients group, $\mathrm{N}=65$ ). For example, a chart review of hospitalized with COVID-19 in Spain reported $19.9 \%$ of patients having insomnia, anxiety, depression, and psychosis (Romero-Sánchez et al., 2020); a meta-analytical study predicts for this group more than 30\% prevalence in PTSD, depression, and anxiety beyond 6 months after discharge (Ahmed et al., 2020). Therefore, it is important to reveal this group's resource change representation.

2. The second group formed involved single male respondents aged from 18 to 34 with low financial income (Male vulnerable group, $\mathrm{N}=42$ ). In a systemic review by Xiong and colleagues, it has been highlighted that single younger men tend to develop higher stress levels during the pandemic (Xiong et al., 2020). Low income was a predictor of more resource loss than social groups who had more resources (especially financial) prior to catastrophic events (Hobfoll et al., 2016); this also was named as one of the main factors contributing to the development of mental health problems in several studies (Xiang et al., 2020).

3. The third group consisted of female respondents aged from 18 to 34 with low financial income who share living space with more than two persons (Female vulnerable group, $\mathrm{N}=32$ ). Sharing living space with more than two persons was included as an indirect indicator of having a family and children. In some studies females showed an increased tendency to develop various forms of mental disorders during the COVD-2019 pandemic (Xiong et al., 2020; Wang et al., 2020), especially mothers who had to combine work and child care within lockdown conditions (Power, 2020).

4. A "resourceful" fourth group consisted of male participants aged from 35 to 54 with high income and ongoing relationships ("Resourceful" group, $\mathrm{N}=54$ ). The group was formed in a logic of inclusion opposite to socio-demographic risk factors mentioned above (Xiong et al., 2020) and as having greater initial financial resource levels (Hobfoll et al., 2016).

Other respondents $(\mathrm{N}=907)$ didn't fit the inclusion criteria for any of the groups. Cohen's d criteria is applied as an effect size significance measure for comparison between particular group means and the mean in the general sample $(\mathrm{N}=1100)$. 


\section{Results}

\section{Resource Loss}

Real loss of resources during 2.5 months after the initial lockdown revealed mostly a less than moderate degree of change. Within the general sample $(\mathrm{N}=1100)$ highest mean scores are within the following resources (Figure 1):

- Financial stability $(\mathrm{M}=2.70 ; \mathrm{SD}=1.50)$;

- Sense of safety (national, family, social, personal) $(\mathrm{M}=2.38 ; \mathrm{SD}=1.40)$;

- Sense of control in Life ( $\mathrm{M}=2.29 ; \mathrm{SD}=1.38)$.

The effect size of comparing means between selected groups and the general group showed the following significant results (Cohen's $d \geqslant 0.3$ ):

1. COVID patients $(\mathrm{N}=65)$ show significantly higher loss in Personal health resource $(\mathrm{M}=2.40 ; \mathrm{SD}=1.17$; Cohen's $\mathrm{d}=0.53)$.

2. Male vulnerable group $(\mathrm{N}=42)$ showed significantly higher real loss rating in Family stability $(\mathrm{M}=2.36 ; \mathrm{SD}=1.46$; Cohen's $\mathrm{d}=0.38)$ and Good relationships with at least one friend $(\mathrm{M}=2.10 ; \mathrm{SD}=1.46$; Cohen's $\mathrm{d}=0.35)$.

3. Female vulnerable group $(\mathrm{N}=32)$ showed significantly more resource loss in evaluating Things and material resources (car, clothes, good food, home etc.) $(\mathrm{M}=2.88 ; \mathrm{SD}=1.48$; Cohen's $\mathrm{d}=-0.62)$, Personal health $(\mathrm{M}=2.25 ; \mathrm{SD}=1.39$; Cohen's $d=-0.39)$, Financial stability $(\mathrm{M}=3.16$; $\mathrm{SD}=1.46$; Cohen's $\mathrm{d}=-0.30)$.

4. Male "resourceful" group $(\mathrm{N}=54)$ rated as having significantly less real loss in Hope and optimism resource $(\mathrm{M}=1.61 ; \mathrm{SD}=1.12$; Cohen's $\mathrm{d}=-0.41)$.

Figure 1

Resource Real Loss Means for the General Sample and Four Formed Comparison Groups

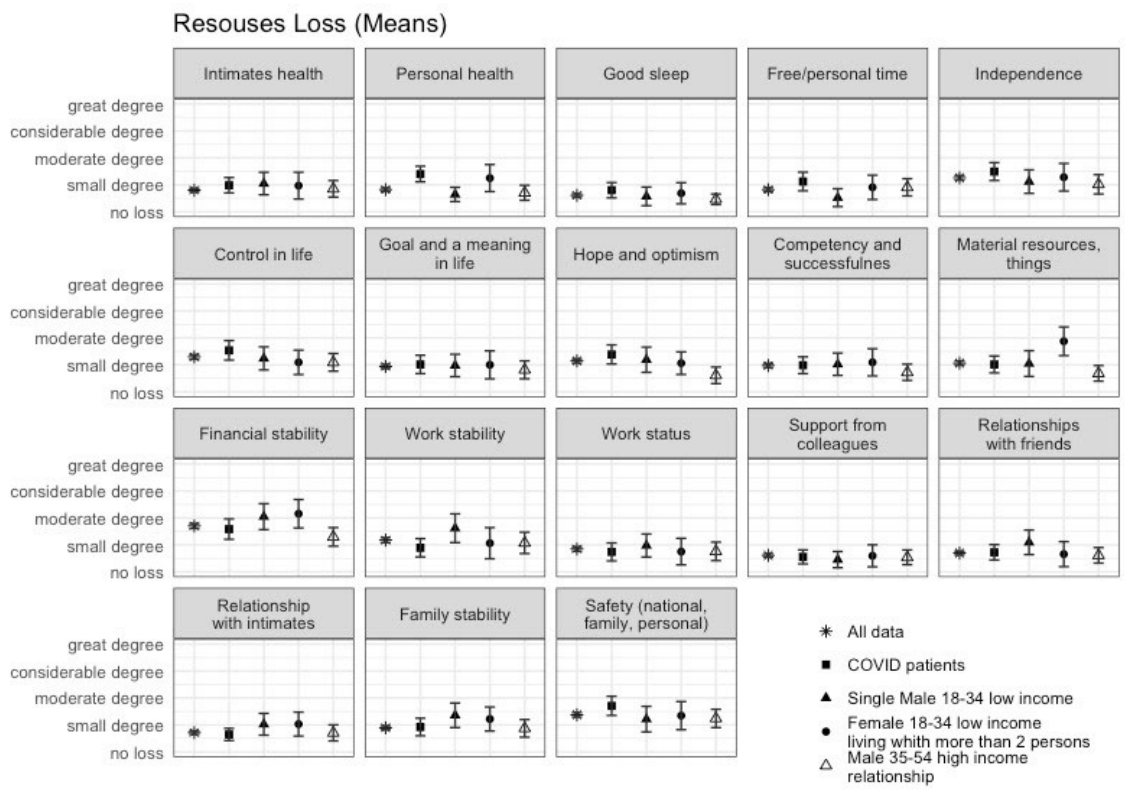




\section{Threat of Resource Loss}

Threat of loss is rated higher in the general sample within the following resources (Figure 2):

- Financial stability $(\mathrm{M}=2.99 ; \mathrm{SD}=1.50)$;

- Sense of safety (national, family, social, personal) $(\mathrm{M}=2.77$; $\mathrm{SD}=1.45)$;

- Intimates' health $(\mathrm{M}=2.54 ; \mathrm{SD}=1.36)$.

Significant differences between particular groups and the general sample in threat of resource loss rating:

1. COVID patients rated significantly higher the threat of losing Sense of safety (national, family, social, personal) $(\mathrm{M}=3.20$; $\mathrm{SD}=1.38$; Cohen's $\mathrm{d}=0.30)$ and Personal health $(\mathrm{M}=2.97 ; \mathrm{SD}=1.24$; Cohen's $\mathrm{d}=0.48)$.

2 . The female vulnerable group had a significantly higher rating in threat of losing Things and material resources (car, clothes, good food, home etc.) $(\mathrm{M}=3.09$; $\mathrm{SD}=1.44$; Cohen's $\mathrm{d}=-0.50$ ).

The male vulnerable group and the male "resourceful" group showed no significant difference from the general sample in rating threat of losing resources.

\section{Resource Gain}

Highest rated resources in resource gain modality within the general sample are (Figure 3):

- Free/personal time $(\mathrm{M}=2.70 ; \mathrm{SD}=1.47)$,

- Good relationship with intimates $(\mathrm{M}=2.44 ; \mathrm{SD}=1.32)$,

- Good sleep $(\mathrm{M}=2.38 ; \mathrm{SD}=1.35)$.

Resource gain rating comparison with the general sample showed an outstandingly and significantly higher rating within the male vulnerable group. A higher gain in this group is found within the following resources: Free/personal time $(\mathrm{M}=3.45 ; \mathrm{SD}=1.52$; Cohen's $\mathrm{d}=0.52)$; Sense of control in life $(\mathrm{M}=2.64 ; \mathrm{SD}=1.45$; Cohen's $\mathrm{d}=0.44)$; Good relationships with at least one friend $(\mathrm{M}=2.57 ; \mathrm{SD}=1.45$; Cohen's d $=0.40)$; Sense of safety (national, family, social, personal $)(\mathrm{M}=2.36$; $\mathrm{SD}=1.48$; Cohen's $d=0.37)$ and Good sleep $(\mathrm{M}=2.81 ; \mathrm{SD}=1.44$; Cohen's $\mathrm{d}=0.32)$.

\section{Resource Value}

The most highly rated value in the general sample is of the following resources (Figure 4):

- Intimates' health $(\mathrm{M}=4.03 ; \mathrm{SD}=1.39)$;

- Personal health $(\mathrm{M}=3.83$; $\mathrm{SD}=1.39)$;

- Good relationship with intimates $(\mathrm{M}=3.82 ; \mathrm{SD}=1.41)$.

1. Free/personal time is checked as more valued in the COVID patients group $(\mathrm{M}=4.02 ; \mathrm{SD}=1.07$; Cohen's $\mathrm{d}=0.30)$;

2. The male vulnerable group rated significantly less value for Personal health $(\mathrm{M}=3.33 ; \mathrm{SD}=1.54$; Cohen's $\mathrm{d}=-0.36)$, Good relationship with intimates 
$(\mathrm{M}=3.38 ; \mathrm{SD}=1.51$; Cohen's $\mathrm{d}=-0.31)$, Sense of a goal and a meaning in life $(\mathrm{M}=3.14 ; \mathrm{SD}=1.62$; Cohen's $\mathrm{d}=-0.31)$.

3. In the female vulnerable group Good relationships with at least one friend as a resource is rated as less valuable compared to the general sample $(\mathrm{M}=3.06 ; \mathrm{SD}=1.66$; Cohen's d $=-0.32$ ).

4. A "resourceful" group rated support from colleagues as having a significantly higher value $(\mathrm{M}=3.00 ; \mathrm{SD}=1.18$; Cohen's $\mathrm{d}=-0.32)$.

\section{Discussion}

We can shortly summarize data discussion with the following conclusions and observations:

1. Within our sample the COVID-2019 outbreak impacted loss in resources to a modest degree. The threat of losing in general is rated higher than real loss. Compared to resource loss and threat reported after other catastrophes and disasters measured with COR-E, we see a much less life-threatening and trauma generating resource change representation (see Freedy et al., 1992).

2. Early stages of the COVID-19 outbreak posed much more threat in an economic sphere (work and financial stability resources as most threatened and lost).

3. A higher rating of the threat of losing a sense of safety (national, family, social, personal) and how it can be linked to personal health calls for further analysis.

4. A somewhat outstanding resource change constellation is revealed in the male vulnerable group, which is defined as at risk in other studies (Xiong et al., 2020). This group showed a greater amount of gain than any other group in our study. This can be explained from the standpoint of one of COR corollaries, which states that resource loss has a much greater impact on psychological distress than resource gain (Hobfoll et al., 2016). Also, there is a significant devaluation of Personal health, Sense of a goal and a meaning in life, Good relationship with intimates resources in this group, so a poor psychological outcome for this group can be explained by an avoidant attachment style, social support deficit as playing a key role in mediating well-being during the COVID-19 pandemic outbreak (Xiong et al., 2020).

5. The female vulnerable group is at most risk within our sample with significantly higher real loss for three resources: Things and material resources (car, clothes, good food, home, etc.), Personal health, and Financial stability. This data supports some evidence that much of the pandemic worries, hardships due to lockdown, and restrictions laid on the shoulders of mothers with young children who had to reconcile work and child care at home (Power, 2020).

6. While the second and third vulnerable groups shared being in a low-income economic status, there was no significant difference in loss and threat of loss to the work-related resources. This could be explained partly by a biased sample: the participants were filling a web-based survey and received payment, thereby they had some free time, internet availability and they are familiar with internet-earnings possibilities. People without such accessibilities at hand might show worse patterns of change in work-related resources. 
7. Support from colleagues and Hope and optimism were more valued and stable resources for the "resourceful" group in comparison to the general sample. This can be an important confirmation that a more burnout-preventing work environment and positive resources such as optimism and hope can boost resiliency (Hou et al., 2018; Shteyn et. al., 2003).

8. Adding a value-scale to the COR-E enriches resource change representation, performs well in statistical terms, and shows good content validity.

9. For the government and social workers, we highly recommend tuning up with intervention policy for immediate and midterm post mass trauma phases (Hobfoll et al., 2007), especially for COVID-19 patients, young persons without relationships and young working mothers with low financial income. Along with COVID-19 spreading, prevention measures, economic support, social and psychological interventions should be aimed at reinforcing mostly impacted resources such as a sense of safety, self- and community efficacy, connectedness, and hope (Hobfoll et al., 2007).

\section{Conflict of Interest}

The authors declare that the research was conducted in the absence of any commercial or financial relationship that could be construed as a potential conflict of interest.

\section{Author Contributions}

FS, MC, NK, conceived of and designed the study; FS, MC collected data; MC, FS, and NK analyzed the data; FS and MV wrote the manuscript; FS, MC, NK edited the final manuscript.

\section{Acknowledgements}

We are grateful to Yana Mikhaylova and Oleg Vasilchuk for their valuable expertise in formulating resource categories for the COR-E modification, to Alexei Balakirev for helping to improve the text stylistically, and to the researchers who share their work on the ResearchGate platform.

\section{References}

Ahmed, M. Z., Ahmed, O., Aibao, Z., Hanbin, S., Siyu, L., \& Ahmad, A. (2020). Epidemic of COVID19 in China and associated psychological problems. Asian Journal of Psychiatry, 51, Article 102092. https://doi.org/10.1016/j.ajp.2020.102092

Cénat, J. M., Blais-Rochette, C., Kokou-Kpolou, C. K., Noorishad, P. G., Mukunzi, J. N., McIntee, S. E., Dalexis, R. D., Goulet, M.-A., \& Labelle, P. R. (2021). Prevalence of symptoms of depression, anxiety, insomnia, posttraumatic stress disorder, and psychological distress among populations affected by the COVID-19 pandemic: A systematic review and meta-analysis. Psychiatry Research, 295, Article 113599. https://doi.org/10.1016/j.psychres.2020.113599 
Davidson, O. B., Eden, D., Westman, M., Cohen-Charash, Y., Hammer, L. B., Kluger, A. N., Krausz, M., Maslach, Ch., O’Driscoll, M., Perrewé, P. L., Quick, J. C., Rosenblatt, Z., \& Spector, P. E. (2010). Sabbatical leave: who gains and how much? Journal of Applied Psychology, 95(5), 953-964. https://doi.org/10.1037/a0020068

Freedy, J. R., Shaw, D. L., Jarrell, M. P., \& Masters, C. R. (1992). Towards an understanding of the psychological impact of natural disasters: An application of the conservation resources stress model. Journal of Traumatic Stress, 5(3), 441-454. https://doi.org/10.1002/jts.2490050308

Gorgievski, M. J., Halbesleben, J. R., \& Bakker, A. B. (2011). Expanding the boundaries of psychological resource theories. Journal of Occupational and Organizational Psychology, 84(1), 1-7. https://doi.org/10.1111/j.2044-8325.2010.02015.x

Halbesleben, J. R., Neveu, J. P., Paustian-Underdahl, S. C., \& Westman, M. (2014). Getting to the "COR" understanding the role of resources in conservation of resources theory. Journal of Management, 40(5), 1334-1364. https://doi.org/10.1177/0149206314527130

Hobfoll, S. E. (2012). Conservation of resources and disaster in cultural context: The caravans and passageways for resources. Psychiatry: Interpersonal and Biological Processes, 75(3), 227-232. https://doi.org/10.1521/psyc.2012.75.3.227

Hobfoll, S. E., \& Lilly, R. S. (1993). Resource conservation as a strategy for community psychology. Journal of Community Psychology, 21(2), 128-148. https://doi.org/10.1002/15206629(199304)21:2<128::AID-JCOP2290210206>3.0.CO;2-5

Hobfoll, S. E., Tirone, V., Holmgreen, L., \& Gerhart, J. (2016). Conservation of resources theory applied to major stress. In G. Fink (Ed.), Handbook of stress: Vol. 1. Stress: Concepts, cognition, emotion, and behavior (pp. 65-71). Elsevier Academic Press.

Hobfoll, S. E., Watson, P., Bell, C. C., Bryant, R. A., Brymer, M. J., Friedman, M. J., Gersons, B. P. R., de Jong, J. T. V. M., Layne, Ch. M., Maguen, Sh., Neria, Y., Norwood, A. E., Pynoos, R. S., Reissman, D., Ruzek, J. I., Shalev, A. Y., Solomon, Z., Steinberg, A. M., \& Ursano, R. J. (2007). Five essential elements of immediate and mid-term mass trauma intervention: Empirical evidence. Psychiatry: Interpersonal and Biological Processes, 70(4), 283-315. https://doi.org.10.1521/psyc.2007.70.4.283

Hou, W. K., Hall, B. J., \& Hobfoll, S. E. (2018). Drive to thrive: A theory of resilience following loss. In N. Morina \& A. Nickerson (Eds.), Mental health of refugee and conflict-affected populations: Theory, research and clinical practice, 111-133. Cham, Switzerland: Springer. https://doi.org/10.1007/978-3-319-97046-2_6

Ironson, G., Wynings, C., Schneiderman, N., Baum, A., Rodriguez, M., Greenwood, D., Benight, C., Antoni, M., LaPerriere, A., Huang, H.-S., Klimas, N., \& Fletcher, M. A. (1997). Posttraumatic stress symptoms, intrusive thoughts, loss, and immune function after Hurricane Andrew. Psychosomatic Medicine, 59(2), 128-141. https://doi.org/10.1097/00006842-199703000-00003

Krishnamoorthy, Y., Nagarajan, R., Saya, G. K., \& Menon, V. (2020). Prevalence of psychological morbidities among general population, healthcare workers and COVID-19 patients amidst the COVID-19 pandemic: A systematic review and meta-analysis. Psychiatry Research, 293, Article 113382. https://doi.org.10.1016/j.psychres.2020.113382

Morelli, N. A., \& Cunningham, C. J. (2012). Not all resources are created equal: COR theory, values, and stress. The Journal of Psychology, 146(4), 393-415. https://doi.org.10.1080/00223980.2011.650734 
Power, K. (2020). The COVID-19 pandemic has increased the care burden of women and families. Sustainability: Science, Practice and Policy, 16(1), 67-73. https://doi.org/10.1080/15487733.2020.1776561

Romero-Sánchez, C. M., Díaz-Maroto, I., Fernández-Díaz, E., Sánchez-Larsen, Á., Layos-Romero, A., García-García, J., González, E., Redondo-Peńas, I., Perona-Moratalla, A. B., Del Valle-Pérez, J. A., Gracia-Gil, J., Rojas-Bartolomé, L., Feria-Vilar, I., Monteagudo, M., Palao, M., Palazón-García, E., Alcahut-Rodríguez, C., Sopelana-Garay, D., Moreno, ... Segura, T. (2020). Neurologic manifestations in hospitalized patients with COVID-19: the ALBACOVID registry. Neurology, 95(8), e1060-e1070. https://doi.org/10.1212/wnl.0000000000009937

Shteyn, M., Schumm, J. A., Vodopianova, N., Hobfoll, S. E., \& Lilly, R. (2003). The impact of the Russian transition on psychosocial resources and psychological distress. Journal of Community Psychology, 31(2), 113-127. https://doi.org/10.1002/jcop.10042

Ten Brummelhuis, L. L., \& Bakker, A. B. (2012). A resource perspective on the work-home interface: The work-home resources model. American Psychologist, 67(7), 545-556. https://doi.org/10.1037/a0027974

Wang, C., Pan, R., Wan, X., Tan, Y., Xu, L., Ho, C. S., \& Ho, R. C. (2020). Immediate psychological responses and associated factors during the initial stage of the 2019 coronavirus disease (COVID19) epidemic among the general population in China. International Journal of Environmental Research and Public Health, 17(5), Article 1729. https://doi.org/10.3390/ijerph17051729

Xiong, J., Lipsitz, O., Nasri, F., Lui, L. M., Gill, H., Phan, L., Chen-Li, D., Iacobucci, M., Ho, R., Majeed, A., \& McIntyre, R. S. (2020). Impact of COVID-19 pandemic on mental health in the general population: A systematic review. Journal of Affective Disorders, 277, 55-64.

https://doi.org/10.1016/j.jad.2020.08.001

Fedor M. Shankov - Researcher, Laboratory of Counseling Psychology and Psychotherapy, FBSSI Psychological Institute of the Russian Academy of Education.

Research Area: spiritual coping, psychotherapy, depersonalization.

E-mail: fshankov@gmail.com

Maria A. Chumakova - Associate Professor, School of Psychology, Department of Social Sciences, HSE University; Researcher, Laboratory of Counseling Psychology and Psychotherapy, FBSSI Psychological Institute of the Russian Academy of Education, PhD in Psychology.

Research Area: risk and decision-making, intelligence and executive functions, neurobiological correlates of cognitive development.

E-mail: mchumakova@hse.ru

Maria S. Vasilchuk - Laboratory Assistant, Institute of Education, Centre for Modern Childhood Studies, HSE University.

Research Area: educational programs for parents, modern parenting.

E-mail: mariya.vasilchuk@gmail.com

Natalya V. Kiselnikova (Volkova) - Head of the Laboratory of Counseling Psychology and Psychotherapy, FBSSI Psychological Institute of the Russian Academy of Education, Ph.D.

Research Area: psychology of personal problem solving, counseling psychology, psychotherapy.

E-mail: kiselnikova-nv@yandex.ru 


\title{
Представления об изменении ресурсов у населения России после первых трех месяцев пандемии COVID-19
}

\author{
Ф.М. Шаньков ${ }^{a}$ М.А. Чумакова ${ }^{a, b}$, М.С. Васильчук ${ }^{b}$, Н.В. Кисельникова (Волкова) ${ }^{a}$ \\ ${ }^{a}$ ФГБНУ «Психологический институт Российской академии образования», 125009, Россия, \\ Москва, ул. Моховая, Ә. 9, стр. 4 \\ ${ }^{b}$ Национальный исследовательский университет «Высшая школа экономики», 101000, Россия, \\ Москва, ул. Мясницккая, д. 20
}

\section{Резюме}

Пандемия COVID-19 несет угрозу психологическому благополучию не только медицинских работников и пациентов, но и общей популяции. Теория сохранения ресурсов С. Хобфолла обладает большим потенциалом для концептуализации последствий и оценки влияния природных и социальных катастроф. Скрининг был проведен в конце мая 2020 года, спустя три месяца после введения ограничений в связи с распространением COVID-19. Получены данные о представлении населения о ценности, утрате, угрозах утраты, приобретении ресурсов в течение данного периода. Выборка: в обработку были включены данные респондентов ( $\mathrm{N}=1100)$, отобранных по специальным критериям для улучшения надежности результатов. Сформировано три группы риска и группа сниженного риска утраты ресурсов: пациенты, перенесшие COVID-19 ( $=65)$; одинокие респонденты мужского пола в возрасте от 18 до 34 лет с низким уровнем финансового достатка $(\mathrm{N}=42)$; респонденты женского пола 18-34 лет с низким уровнем достатка и проживающие с двумя и более лицами $(\mathrm{N}=32)$; «ресурсная» группа, состоящая из респондентов мужского пола от 35 до 54 лет с высоким достатком и в отношениях $(\mathrm{N}=54)$. Для анализа данных были использованыа описательная статистика и критерий Коэна для сравнения групп. Методики: социальнодемографическая анкета; модифицированная версия опросника сохранения ресурсов. Результаты: в целом по выборке доступность ресурсов изменилась в небольшой степени. Угроза утраты ресурсов больше их реальной потери. Особенно были затронуты финансовая стабильность, чувство безопасности, чувство контроля над жизнью, чувство независимости, здоровье близких, стабильность работы. Сравнение групп обнаруживает значимые различия, которые согласуются с исследовательской литературой. Рекомендуется обращение к опыту применения социальных и индивидуальных интервенций, направленных на предотвращение негативных психологических последствий коллективной травмы и укрепление чувства безопасности, само- и социальной эффективности, чувства единства и связанности, надежды.

Ключевые слова: личные ресурсы, COVID-19, теория сохранения ресурсов, ценность ресурсов, стресс, изоляция, совладание, жизнеспособность.

Шаньков Федор Михайлович - научный сотрудник, лаборатория консультативной психологии и психотерапии, ФГБНУ «Психологический институт Российской академии образования».

Сфера научных интересов: духовное совладание, психотерапия, деперсонализация.

Контакты: fshankov@gmail.com 
Чумакова Мария Алексеевна - доцент, департамент психологии, факультет социальных наук, Национальный исследовательский университет «Высшая школа экономики»; научный сотрудник, лаборатория консультативной психологии и психотерапии, ФГБНУ «Психологический институт Российской академии образования», кандидат психологических наук.

Сфера научных интересов: психология риска и принятия решений, интеллект и исполнительные функции, нейробиологические корреляты когнитивного развития.

Контакты: mchumakova@hse.ru

Васильчук Мария Сергеевна - лаборант, Центр исследований современного детства, Институт образования, Национальный исследовательский университет «Высшая школа экономики».

Сфера научных интересов: родительские образовательные программы, современное родительство.

Контакты: mariya.vasilchuk@gmail.com

Кисельникова (Волкова) Наталья Владимировна - заведующая лабораторией, лаборатория консультативной психологии и психотерапии, ФГБНУ «Психологический институт Российской академии образования», кандидат психологических наук, доцент.

Сфера научных интересов: психология решения личностных проблем, консультативная психология, психотерапия.

Контакты: kiselnikova-nv@yandex.ru 